\title{
CGによる物体の燃焼と変形・変色の表現
}

\section{Computer Graphics Representation of Deformation and Color Change in Objects during Combustion}

\author{
正会員 佐 藤 吉 将†*, 正会員 島 田 英 之 ${ }^{\dagger}$, 正会員 塩 野 充 ${ }^{\dagger}$, 正会員 宮 垣 嘉 也† \\ Yoshimasa Satou $^{\dagger *}$, Hideyuki Shimada ${ }^{\dagger}$, Mitsuru Shiono $^{\dagger}$ and Yoshiya Miyagaki ${ }^{\dagger}$
}

\begin{abstract}
Research into the the representation of flames using CG has focused on flame representation. There has been little research into the relation between the flame and the burning object. The burning object has been interpreted as the fuel resource, that is, the combustion root, or as an obstruction to the flame's motion. In this paper, we interpret combustion as deformation of both the flame and the objects and propose a CG representation method. The representation subject is the object which occured the shrinking deformation. Before our experiments, we observed actual scenes of combustion, then based on these observations, we represented the deformation and the color change. In this method, the burning object is modeled using 3D volume data, and the control parameters are set to these. The deformation and color change are represented by changing the parameters with cellular-automata and a heat equation. Our experiments showed that our method more realistically represents combustion and deformation, particularly of wood.
\end{abstract}

キーワード：CG，炎，燃焼，燃焼物体の変化

\section{1. まえがき}

自然界の情景をコンピュータグラフィックスにより表 現する試みは以前から行われており，その中でも炎はそ の身近さと，表現手法の複雑さから，これまでに多くの 研究が行われてきた ${ }^{1)-10)}$. しかし，炎の表現方法につ いては多くの研究例があるものの，炎と物体との係わり についてはほとんど研究例がなく，文献 11)12) などがあ るのみである。これらのモデルでも，物体は燃焼経路の 指定のための燃料源として考えているか，あるいは，炎 の動きを制限する障害物としてのみ捉えている。しかし， 物体が燃焼する際には，そこから炎が発生するというだ けではなく，燃焼に伴って物体の変色や変形という現象 が存在するのが普通である。このことについての具体的 な考察はこれまであまり行われていない.

そこで本論文では，燃焼に伴う物体の変形や変色の過 程に着目し，これを CGにより表現する一手法について 提案する ${ }^{13)}$.

2000 年 12 月 21 日受付, 2001 年 4 月 4 日再受付, 2001 年 5 月 8 日採録 †岡山理科大学 工学部

(₹ 700-0005 岡山市理大町 1-1 Tel(086)256-9507

*現在，株式会社ケイ・ジー・ティー テ 160-0022 東京都新宿区新宿 2-8-8 とみん新宿ビル $\mathrm{Tel}(03) 3225-0741$

$\dagger$ Facalty of Engineering. Okayama University of Science

(1-1, Ridai-cho, Okayama-shi, 700-0005 Japan)

*KGT Inc., Tomin Shinjuku Bldg., 2-8-8, Shinjuku, Shinjuku-ku, Tokyo, 160-0022 Japan
燃焼に伴う物体の変形や変色の仕組みについて直ちに 応用できる物理的な考察を行った研究例を見出すことが できなかったので，本論文では，実際の物体を燃焼させ， その変形と変色の様子を観察し, そこから変形と変色の 規則を仮定して，CGにより表現する方法をとった。

この論文の手法により，炎が物体に燃え移り，そこか ら発生した炎がまた別の物体へと燃え移っていく様子が 表現可能となり, また, 物体の変形と変色の様子の表現 についても，主観的には目的とするシーンを得ることが できたと考えられる。なお，本研究のアルゴリズムは， 木のような収縮変形する物体の燃焼と変形の表現を目的 としており，薄い紙のように非常に大きく変形するよう な物体については対象としていない.

本研究を更に発展させれば，建造物の火災シミュレー ション 14)15) や, 映像の特殊効果など, 仮想空間内での 燃焼・延焼の表現へ応用することができる。

\section{2. 観察による燃焼規則の設定}

実験を始める前に，燃焼の規則を設定するため，実際 の物体に火を付け, 外観的な燃焼の過程を繰り返し観察 した．実際の燃焼の様子の一例として，図 1 が得られ， これらの結果から, 最小限以下の燃焼規則を抽出し設定 する。

・物体は, 外側から内側に向かって収縮するように変 形する.

映像情報メディア学会誌Vol. 55, No. 7, pp. 1026〜1034（2001） 


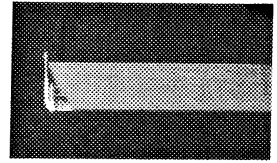

$(\mathrm{a}-1)$

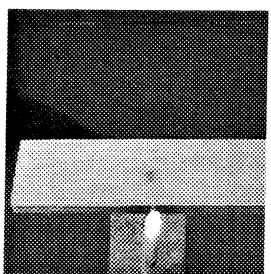

(b-1)

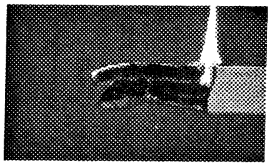

$(\mathrm{a}-2)$

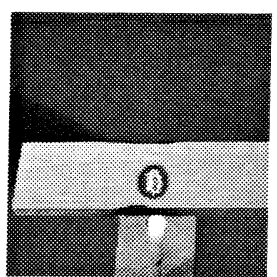

(b-2)
図 1 実際の物体の燃焼結果の例。

Some examples of the real combusted objects.

・物体は初期の頃は燃焼箇所に沿って, 変形・変色す るが，燃焼が進むにつれ，変形は行われなくなり，燃焼 と変色のみが進行するようになる.

・薄い板状の物体の中央から火を付けた場合，燃焼の 進行に伴い，そこに穴が開く.

・炎は上昇する性質があるため，上方向への燃焼は進 行しやすく，下方向には燃焼はほとんど進行しない。

本論文での物体の燃焼による変形・変色は以上の規則 を表現することを目的とする。

\section{3. 粒子と渦場を用いた炎のモデリング}

炎そのものをモデリングする手法についてはすでに多 くの研究がなされている。ここでは粒子と渦場を用いた 炎のモデリング手法を用いた。詳細については文献 ${ }^{3)} に$ あるので，ここでは要点を列記する。

（1）シミュレーション空間中に炎を表す点（粒子） を多数発生させる.

（2）発生した粒子に上昇力を表すべクトルと，炎を ゆらめかせるための 3 次元の渦場を用いた乱流の ベクトルを加える。また，炎の火先を表現するた め, 互いの粒子間に引力のベクトルを持たせる. これら 3 つのベクトルの和を速度ベクトルとする.

（3）シミュレーションの各タイムステップごとに先 ほど定めた速度べクトルによって粒子を移動させ る。なお夕イムステップ内での粒子の運動は直線 運動のみとする。

（4）粒子には熱量 $T$ が設定されており，この熱量は シミュレーションのタイムステップごとに一定值 $\Delta T$ ずつ減少させる。熱量が 0 になった時点で, 粒子をシミュレーション空間から消失させる。 な お, 本シミュレーションでは $T$ の初期值を 1 と設 定しているため，実際には粒子の寿命は $1 / \Delta T$ と なる.

炎の色と粒子間の補間方法については，4.1 のボクセ ル空間を用いるため, 後章で説明する.

\section{4. 燃焼物体の表現方法}

\section{1 燃焼物体の構成}

シミュレーション空間は, 3 次元空間を格子状に区切っ た立方体型ボクセルの 3 次元配列により構成される。燃 焼物体はボクセルを最小単位として構成され，物体のな い領域は空間領域となる。物体の燃焼を表現するパラ メータとしては, 表 1 に示す 1 つの物体に共通したパラ メータと, 表 2 に示す各ボクセルごとに設定されるパラ メータがある.1つの物体に共通したパラメー夕は，そ の物体の燃焼の様子をコントロールするためのパラメー タであり, シミュレーション開始前に設定した後は更新 されることはない. 一方, ボクセルのパラメー夕はその セルの現在の状態を示しており, 燃焼の進行に伴い変化 する.

各パラメータの詳細については, それぞれ 4.3 から 4.6 の記述の中で説明する.

\section{2 炎と物体との衝突判定}

シミュレーション空間中を移動する炎の粒子が物体と 衝突した時，粒子の持つ熱を衝突したボクセルに与え， また衝突後，物体を通り抜けないように移動方向の修正 を行う必要がある。そこで以下の手順により炎の粒子と 物体を構成するボクセルとの衝突判定を行い, 熱の受け 渡しと, 粒子の移動方向の変更を行った。

（1）炎の粒子は 1 タイムステップ内では，直線運動 のみとしているので, $3 \mathrm{DDDA}^{16)}$ を用いて，炎の 粒子が通るボクセルを求め, 最初に炎と物体が衝 突したセルを決定する.

（2）衝突したセルに炎の粒子が持つ熱を伝達し，粒 子の持つ熱を減少させる。本手法では, 計算の簡 略化のため, 粒子が単位タイムステップあたりに 減少する熱量をボクセルに与え, 粒子の熱量を同 じ量だけ減少させることとする。これにより，粒 子の存在時間は 1 タイムステップ分短くなること になる。

（3）衝突後の炎の粒子の移動方向を衝突面に沿うよ うに変化させる。

（4）もし, 計算結果の粒子の移動先が物体のボクセ ル内に入るようであれば, 計算の簡略化のため, その粒子は面に沿って移動しなかったものとして， 粒子が衝突する 1 つ手前のボクセル内でランダム に移動先を設定し，その位置に移動させる。

\section{3 熱伝導規則}

1 つの物体に火がついて燃え広がる様子を表現するた めに物体内の熱伝導の計算を行う必要がある. 本手法で は, 3 次元非定常熱伝導式 ${ }^{17)}$ を元に, 熱伝導を単調増加 させるように修正を加えた式を用いた。

また，外側から内側へと燃焼を進行させるために，夕 イムステップごとに各ボクセルごとに空間ボクセルから 
表 11 つの燃焼物体に共通したパラメータ.

Common parameters of a combustible object.

\begin{tabular}{l|l}
\hline \hline 発火点 $\left(T_{i g}\right)$ & 物体の発火温度. 温度がこの值以上になれば発火する. \\
\hline 体積変化度の隇少量 $\left(V_{c c}\right)$ & タイムステップあたりの物体の体積変化度の隇少量. \\
\hline 初期燃料 $\left(F_{0}\right)$ & 物体の燃料の初期値. 物体の変色に用いる. \\
\hline 熱伝達度 $(C)$ & 物体固有の熱の伝達度. \\
\hline 内外の熱伝達変化係数 $\left(C_{i}\right)$ & 物体内外での熱の伝達に差をつけるための係数. \\
\hline 上下方向への熱の伝達変化係数 $\left(C_{u d}\right)$ & 熱伝達に上下方向の差をつけるために用いる. \\
\hline 色相 $(\mathrm{H})$ & 物体の色相情報. \\
\hline
\end{tabular}

表 2 各ボクセルが持つパラメー夕.

Parameters of each voxel.

\begin{tabular}{l|l}
\hline \hline 温度 $(T)$ & 要素の現時点での温度. \\
\hline 体積 $(V)$ & ボクセル内を物体がどのくらい占めているかを表す. \\
\hline 燃料 $(F)$ & 発生させることのできる炎の粒子の残量. 変形可能な時間も表す. \\
\hline 彩度 $(S)$, 輝度 $(\mathrm{I})$ & ボクセル固有の色情報. これらと物体の色相によりボクセルの色が決定される. \\
\hline 体積変化度 $\left(V_{c}\right)$ & 単位タイムステップあたりの体積隇少量. \\
\hline 街区画距離 $(d)$ & 単位タイムステップごとに求める. 熱伝達, 変形に用いる. \\
\hline 街区画距離の初期値 $\left(d_{o}\right)$ & シミュレーション開始前にのみ設定される. 変形度の減少に用いる. \\
\hline 発火フラグ & そのセルが発火状態であるかどうかのフラグ. \\
\hline
\end{tabular}

の街区画距離 ${ }^{18)}$ を計算し，同じ街区画距離を持つボク 七ル間での熱伝達に比べ，異なる街区画距離を持つボク セル間での熱伝達を低くする。これにより，通常の熱伝 導とは異なり，火点から遠い䇢所であっても物体の外側 のほうが内側よりも速く熱が伝わることとなり，外側か ら内側に向けて燃焼が進行することになる。

また，燃焼が上方向へと進行しやすく，下方向へは進 行しにくい様子を表現するため, 下のセルからは多くの 熱量を受け取るが，上のセルからはほとんど熱を受け取 らないように係数を設定する。

これらの規則を導入した熱伝導の概念図を図 2 に示 し，そのアルゴリズムを以下に記述する。ここで，Tは セルの温度, $d$ はセルの街区画距離, $C$ は熱の伝達係数 を表すままた，温度計算における更新前後の温度の混在 を防ぐために，温度を一時的に保存するための一時領域 $T_{t e m p}$ を設けてある。また， $C_{i}$ は異なる街区画距離間で の熱伝達を減少させるための係数であり, $0<C_{i} \leqq 1$ と する. $C_{i}=1$ のときは, 通常の熱伝達と同じ進行過程と なる. $C_{u d}$ は上下方向に熱の進行状態を変化させるため の係数であり, $0 \leqq C_{u d}<1$ とする. $C_{u d}=0$ のときは, 上下方向への熱の進行の違いは発生しない.このアルゴ リズムでは，熱伝導の境界条件として温度計算は，炎の 粒子から熱を受け取っていないセルについてのみ行い， 粒子から熱を受け取ったセルについては，このアルゴリ ズムによる温度変化はないものとする。

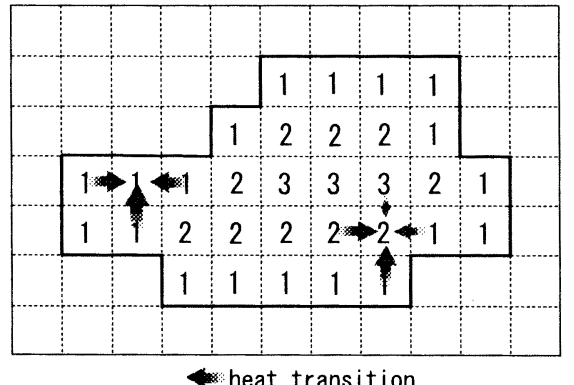

図 2 街区画距離を用いた熱伝導の変化の様子. The transition of heat conduction using city-blockdistance.

ここで, $x, i$ はシーンの横方向 (右を正) $, y, j$ はシー ンの縦方向 (上を正), $z, k$ はシーンの奥行き方向 (手前 を正)のボクセルの座標を表している.

procedure heat_conduction();

function $\operatorname{conduct}(x, y, z, i, j, k)$;

begin

\{ 街区画距離が異なる場合は， $C_{i}$ により熱の伝達を小さくする， \} if $d[x][y][z]<>d[i][j][k]$ then

$$
c d:=C_{i} \text {; }
$$

else

$$
c d:=1.0
$$

conduct : $=C * c d *(T[x][y][z]-T[i][j][k]) ;$

\{負の温度伝達をなくすことで,

温度は単調増加する．\}

if conduct $<0.0$ then conduct $:=0.0$; 
return conduct

end;

begin

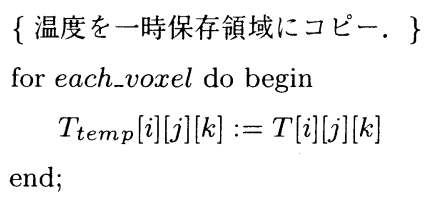

\{上下方向の温度伝達に差をつけながら，

温度の伝達を行う。\}

for each_voxel do begin

\{炎の粒子から熱を受け取っていない

セルのみ計算する。

if ( voxel $[i][j][k]$ is no_heated_object_cell ) then begin

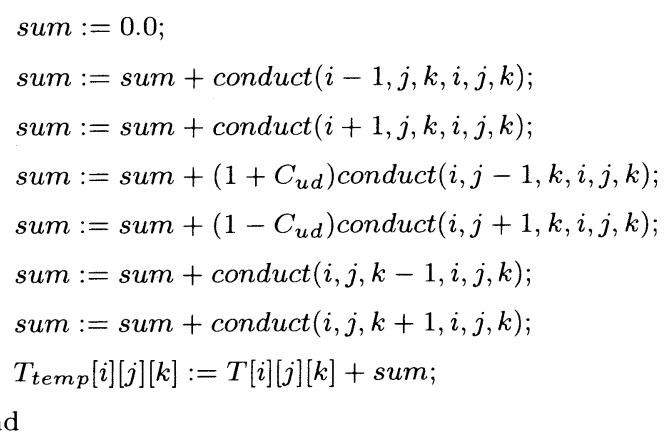

en

end;

\{更新された値を元の配列に戻す． \}

for each_voxel do begin

$T[i][j][k]:=T_{\text {temp }}[i][j][k]$

end

end;

\section{4 物体の発火と変色}

炎から物体への熱の授与と熱伝導により，最外殼ボク セル $(d=1)$ の温度が発火点以上になった時, そのボク セルは発火状態に達したものとし, ボクセルの発火フラ グを立てる。発火フラグの立ったボクセルの周囲の空間 領域のボクセルから一定個数の炎の粒子を発生させる. なお, 物体内部のセルは, 温度が発火点以上になったと しても, 周囲のセルは全て物体であることから炎の粒子 を発生させることはできないと考え, 発火状態にはし ないものとする。ボクセルが発火状態になった場合, ボ クセルが持つ燃料を 1 ターンに 1 単位ずつ減らす。燃料 が無くなったセルについては発火できなくなったセルで あると見なし, 炎の発生を停止することで, 鎮火を表現 する.

また, 物体の変色過程を表現するため, 物体の色を初 期に設定されている色から黒色へと変色させていく．具 体的には，タイムステップごとに以下の式 (1) を用いる ことで変色の表現を行う.

$$
\begin{aligned}
& H_{t+1}=H_{t} \\
& S_{t+1}=S_{t}-\frac{1}{F_{0}} \\
& I_{t+1}=I_{t}-\frac{R}{F_{0}}
\end{aligned}
$$

ここで, $F_{0}$ は, シミュレーション開始時に各物体に 設定されている初期の燃料を示す。また， $H_{t}, S_{t}, I_{t}$ は現時点でのボクセルの HSI 系の色を表している $(0 \leqq H<360,0 \leqq S, I \leqq 1)$. $H$ は物体固有の色情 報であるため, シミュレーション開始から終了まで変化 しないものとする. $S, I$ のパラメータを変化させること により, 物体の変色を実現する。輝度 $I$ については燃焼 後の物体の色が単調にならないようにするため, 乱数項 $R$ により変化させてある，計算された色をこのボクセル の色として，後述のレンダリングの際に使用する.

\section{5 物体のレンダリング}

各ボクセルが現在保存しているパラメータを元に， 物体のレンダリングを行う。ここでは，体積值 $V$ をボ リュームデータとして物体の描画を行う。体積值は物体 によるボクセルの占有度を表しており， $V=1$ はボクセ ルが完全に物体で満たされている状態であり，值が小さ くなるに従い, ボクセル内には物体が存在していないと いう状態を表す。初期状態では，物体には 1 の体積値を， 空間領域には 0 の体積値を与えておく.

本研究では燃焼する物体の内部が見える必要はなく, また，ボクセルに設定されたパラメータから複雑な計算 を介することなく形状を決定したいという点から，マー チンキューブ法による描画方法を採用した ${ }^{19)}$. ボクセル の持つ体積值をボリュームデータとして, 等值面を作成 することにより，物体のレンダリングを行った。

\section{6 物体の変形アルゴリズム}

セルが発火状態になった場合，タイムステップごとに 物体の体積値から各セルにあらかじめ設定してある体積 変化度を引き，七ルの体積を減少させることで物体の収 縮変形を表現する。物体の変形は，セルが発火している 間のみ行われ，未発火状態あるいは鎮火している状態で は変形は行われないものとする. 4.3 により, 温度の進 行過程が外側から内側に進行するようになっているので， 基本的には物体の変形過程も外側から内側へと進行して いくことになる.

体積変化度はシミュレーション開始前には, 各ボクセ ルごとに同じ值が設定されているので，このままでは值 によっては，途中で収縮が止まることはなく，物体の要 素が全て消えることとなってしまう。そこで，タイムス テップごとに以下の規則を適用することにより，体積変 化度を小さくしていくことで，徐々に変形量を小さくし， 燃焼の進行に伴い, 物体の変形が行われにくくなるよう な処理を行う。ここで， $d_{o}$ とは，シミュレーション開始 前に設定される各ボクセルにおける街区画距離であり, $d$ のように, 単位タイムステップごとに変化することは 
ない.

アルゴリズムを以下に示す.

procedure change_Vc();

begin

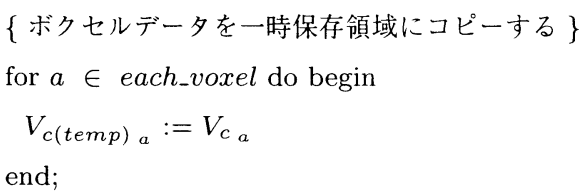

for $a \in$ each_voxel do begin

\{隣接要素が発火しているのなら実行 \}

if some_neighbor_voxel is ignitte then begin $\min :=V_{c_{a}}$

\{隣接するセルのうち, 注目セルよりも

温度が高く, かつ, 距離 $d$ が低いセルの なかで, 最小の変形度を求める $\}$

for $l \in$ 6neighbors do begin

if $T_{l}>T_{a}$ and $d_{l}<d_{a}$ and

$V_{c_{l}} \leqq \min$ then $\min :=V_{c_{l}}$

end;

$\{$ 初期の街区画距離によって

変形の大きさを変える $\}$

$\min :=\min -V_{c c}\left(d_{o_{a}}-1\right)$;

\{ 現在の $V_{c_{a}}$ よりも小さい值に更新する $\}$

if $\min <V_{c_{a}}$ then

$V_{c(t e m p)_{a}}:=\min$

end

end;

\{計算されたデータをもとの变数領域にもどす $\}$

for $a \in$ each_voxel do begin

$V_{c_{a}}:=V_{c(t e m p)}{ }_{a}$

end

end;

ここで， $V_{c}\left\{0 \leqq V_{c} \leqq 1\right\}$ は，物体の体積変化度を表し， $V_{c c}\left\{0 \leqq V_{c c} \leqq 1\right\}$ は単位夕イムステップあたりの体積変 化度の減少量を表している。初期距離 $d_{o}=1$ のセルに ついては，開始前に設定された体積変化度のままでセル の体積值が減少することとなるが, 変形が進行するに従 い, 内側のセルでは小さな変化度で収縮するようになり, やがて，変形が止まることとなる。

体積值が一定值以下になったセルについては，物体を 構成していないセルであると判断し，これを空間セルに 置き換える。これにより，物体の外周にあったセルは， 燃焼の進行に伴って，消えて行くことになる．体積変化 度の值によっては，セルの燃料が尽きていない場合で あっても，そのセルを空間セルに置き換える。
外側のセルが空間セルに置き換えられた時，内側のセ ルの温度が発火点に達していない場合もあり，そのまま では発火もしておらず，まったく変色していないセルが 表示されてしまうこととなる。熱伝達速度と変形度のパ ラメータを調整することにより，内側のセルが見え始め るのと同時にそのセルを発火するようにすることは可能 ではあるが，適切なパラメー夕を設定することは困難で ある。そこで，街区画距離 $d=2$ のセルについて，周囲 の発火しているセルの $S, I$ それぞれを平均した值を，そ のセルの色情報として常に設定しておく。これにより， 外側のセルが消失した時点の色が内側のセルにセットさ れていることになり，この色を初期值として，式 (1)に よる変色を行なう.

また，セルを空間セルに置き換えるときには，強制的 にその周囲の物体セルの発火フラグを立てる。

これらにより, 温度が発火点未満でも発火しているこ ととなるが，見た目としては内部方向に収縮しながら然 焼しているように燃焼過程が進行することになる。

\section{5. 炎の補間方法}

\section{1 ドロネー図を用いた炎のレンダリング}

3 でモデリングされた炎をそのままレンダリングする と粒子間の隙間が目立つため，多数の粒子を用いて隙間 が目立たないようにするか，なんらかの補間手法を用い て隙間を埋める必要がある。本手法ではドロネー図 ${ }^{20)}$ を用いて粒子間をポリゴンにより補間し，炎をサーフェ イスモデルとして表現する ${ }^{10)}$ 。これにより少ない粒子で 複雑な形状をした炎を表現することが可能となる。

\section{2 ドロネー図}

ドロネー図とは，実数空間中にある頂点集合を三角形 により補間したものである。これらの三角形は互いに交 差することがなく，またできるだけ細長い三角形を持た ないという特徴がある。このため，頂点間の接続関係を あらかじめ定義できない物体をポリゴンにより表現する のに適したアルゴリズムであると言える。本手法では炎 の粒子をドロネー図の頂点と見立て，3次元のドロネー 図作成アルゴリズムを適用することにより炎をサーフェ イスモデルで表現する。

\section{3 透明粒子を用いた炎の表現}

通常のドロネー図は凸包しか構成できないという特徽 があるため，このままでは炎の持つ凹みを表現すること はできない。そこで本論文では，以下の手法により，炎 の粒子の周囲に透明な粒子を配置し, それを含めてドロ ネー図の計算を行うことで, 物体の凹みを表現した。こ の時の概念図を図 3 に示す.

（1）各タイムステップごとに，物体を構成している ボクセル空間において，炎の粒子が存在している ボクセルに印を付ける。

（2）印をつけたセルとその 26 近傍のセルについて， 


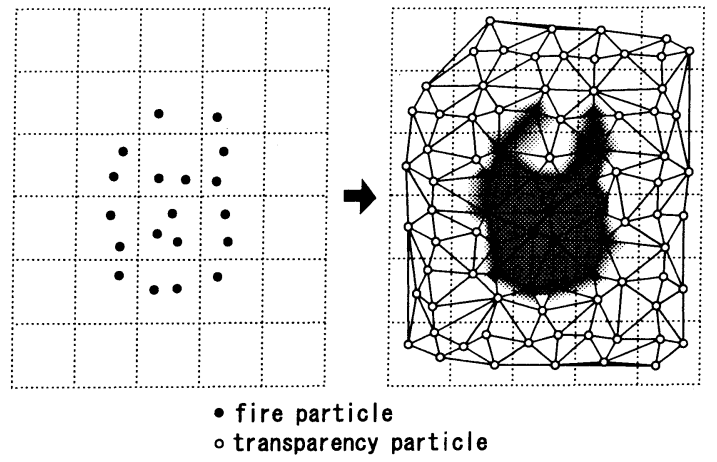

図 3 ドロネー図と透明粒子を用いた炎の構成。 The structure of flame with Delaunay Triangulation and transparency particles.

ある一定個数になるまで透明な粒子をセル内にラ ンダムに配置する。もし炎の粒子が䦐値以上あれ ば，そのセルには透明粒子は配置されない，逆に 炎の粒子が存在していない周囲のセルには閯值個 の透明な粒子が配置される。

これにより，炎の凹みを表現することができ，また， 炎の境界をぼやけさせるような炎を構成することがで きる。

各ポリゴンの頂点は粒子の持つ熱量に応じて透明度が 設定され，火先に近付くにつれて透明度は高くなる。こ れにより，後ろの炎や景色が透過するようになり，炎の 持つ半透明感を表現することが可能となる．炎の色な らびに透明度は，炎の粒子が持つ熱量により，式 (2)に より表される。炎の色は，発生箇所に近い場所は黄色が かった白色とし，火先に近付くにしたがって，黄色から 赤色へと変化させるものとする.

$$
\begin{aligned}
& H=60 T \\
& S=-0.4 T+1 \\
& I=0.2 T+0.1 \\
& A=-\sqrt{1-T}+1
\end{aligned}
$$

ここで, $T$ は粒子が持つ熱量であり, 1 から 0 へと変化す るものである. また， $H, S, I$ はそれぞれ，頂点の HSI 值 を表し，A は粒子の不透明度を表す $(0 \leqq H \leqq 60 ， 0 \leqq$ $S, I, A \leqq 1)$ ．なお，ときおり透明粒子がうまく炎の粒 子の外縁部に存在せず，大きなポリゴンが描画されてし まうこともあるので，粒子間の距離がある一定值以上に なったポリゴンは描画しないようにする.

\section{6. 燃焼シーンの構成}

\section{1 シーン全体の処理の流れ}

以上述べた各技法を組み合わせた燃焼のアニメーショ ンシーンを構成する。その手順は以下の通りである。

（1） シミュレーション空間中に物体を表すボクセル 領域を設定し，各物体，ボクセルにパラメー夕を 設定する。 また，この時，街区画距離の初期值を
計算し，各ボクセルに保持する.

（2）シミュレーション空間中に乱流場を形成するた め, ランキン渦 ${ }^{3)}$ を複数個発生させる. 渦は他の 渦の影響を受けて移動し，また寿命の尽きた渦は シミュレーション領域から削除する。

(3) 空間中の任意の箇所から炎の粒子と透明粒子 を発生させ，移動させる．寿命の尽きた粒子はシ ミュレーション領域から削除する。

（4）炎の粒子が単位タイムステップ当たりに通るボ クセル列を 3DDDA を用いて求める.

（5）炎の粒子と物体との衝突判定を行う。もし衝突 すれば，物体面に沿うように粒子の移動方向を変 化させ，粒子の持つ熱の一部を衝突箇所のボク セルに与える。また，同量の熱量を粒子から差し 引く.

（6）物体を構成する各ボクセルに対し, 温度伝達の アルゴリズムを適用し，温度の伝搬を行う。

（7）要素の温度が発火点以上である場合，そのセル に発火フラグを立てる。

（8）発火フラグが立っており，かつ燃料があれば, そのセルから炎の粒子を発生させ，燃料を隇少さ せてゆく．物体の色は燃料の減少に伴い，初期の 色から徐々に黒色に変色させていくこのとき, 内側のセルについても，同じ色を設定する。

（9）燃焼中は，各セルに設定されている変形度を体 積から引くことで, 物体の収縮変形を表現する.

（10）変形の結果，ボクセルが物体の外側であると判 定された場合には，そのセルを空間セルに置き換 える。また，そのセルの周囲の物体のセルに，発 火フラグを設定する。

（11）変形を途中で終了するために，体積変化度を減 少させる計算を行う。

（12）体積值を元に，マーチンキューブ法により，物 体の境界面を表示することで, 物体の描画を行う。

（13） シーン中のすべての炎の粒子と透明粒子をドロ ネー図を用いて結合し，ポリゴンデータを生成す る。生成されたデー夕を元に，炎の描画を行う.

以上の過程の内, $(2) \sim （ 13)$ をシミュレーション中 に繰り返し実行する。

\section{7. 検 証 実 験}

\section{1 実験環境}

各種パラメータを変化させた場合のシーンへの影響を 調べるため，以下にいくつかの実験例を示す。実験には PentiumIII, $500 \mathrm{MHz}$ ，メモリー搭載量 $360 \mathrm{MB}$ の計算機 を使用し，描画には一般に市販されている 3 次元画像処 理ボードを用いた。シーンの実装には OpenGL APIを 用いている。 


\section{2 収縮変形の実例}

棒状の物体を燃焼させ，収縮変形を行なう様子を 示した 1 例を図 5 に示す.物体の大きさは $60 \times 10 \times 10$ である。物体のパラメータとして，図 5-(a)の物体に は, $T_{i g}=0.6, V_{c c}=0.003, F_{0}=15, C=0.5, C_{i}=$ $0.00001, C_{u d}=0.9$ ，初期の $V_{c}=0.1$ を設定している. 図 5-(b) の物体については, $C_{i}=1.0$ 以外については (a) の物体と同じである。結果画像より，燃焼が進行するに 従い，収縮変形が行なわれている様子がわかる。また， 温度伝達に内外差がある場合には，外側から内側への変 形が行なわれるため，芯が残るように変形しているが， 温度伝達の内外差が少なくなると，端から順に燃焼する ようになり，芯が残りにくくなることがわかる.

\section{3 発火場所の違いによる燃焼の変化}

同じ物体で，火を付ける場所を変更することによる変 形の違いを調べるため，図 6 に示すように，中央から 火を付ける場合 (a) と，端から火を付ける場合 (b) の2 つの例を実行した，各物体は $50 \times 50 \times 4$ の大きさであ る.また，制御パラメータについては， $T_{i g}=0.6, V_{c c}=$ $0.007, F_{0}=10, C=0.3, C_{i}=0.00001, C_{u d}=0.9$ ， 初期 の $V_{c}=0.15$ としている.

図より，中央から火を付けた場合には，そこから穴が 開くという変形が表現されていることが分かる。また， 同じ物体であっても，火を付ける箇所が異なれば，燃焼 後の形状が変わるということが表現されている.

\section{4 上下の熱伝達の違い}

次に,「ト」の文字の形の物体を燃焼させ，上下方向への 熱の伝達差の確認を行った，その時の様子を図 7 に示す. 左側の物体のパラメー夕は $T_{i g}=0.6, V_{c c}=0.004, C=$ $0.5, C_{i}=0.00001, C_{u d}=0.9$ ，初期の $V_{c}=0.06$ ，右側の 物体のパラメー夕は $C_{u d}=0.2$ 以外は左側の物体と同じ パラメータである。

実験結果に見られるように，左側の物体は上方向へは 燃焼の進行が速く，下方向へはあまり進行していないこ とがわかる。しかし，パラメー夕を変化させても上方向 への進行速度にはあまり顕著な変化が見られず，下方向 のみ進行速度の変化が見られた。これは熱伝達の影響を 受ける以前に，発生した炎自体により上側のセルが然焼 されるためであると考えられる。

\section{5 シーンへの適用例}

シーンへの適用例として，図 8 のような部屋を作成し， 部屋が燃えていくアニメーションを作成した。これより， ボクセルを最小単位とした自由なシーンの燃焼表現が可 能になったと言える。

なお, 各実験における 1 フレームあたりの平均粒子数 (炎の粒子十透明粒子の平均) と平均実行時間を表 3 に示 す。これにより，演算時間はおもに発生する粒子数に依 存することがわかる.

以上の結果より，2 で目標として設定した，燃焼に伴
う物体の収縮表現を表現することができたと言える。ま た，パラメータを変化させることにより，燃焼の進行状 態を制御することもできた。

\section{6 ボリュームレンダリングとの比較}

炎の描画には，現在ではボリュームレンダリングが多 く用いられている 21)22)。それらと本手法との比較を行 うために，ボリュームレンダリングと本手法で同じシー ンを描画し，その所要時間を調べた。計算時間を表 4 に示す。また，実行例を図 4 に示す。ここで，1particle， 2particles とは単位タイムステップあたりに発火状態の セルの周囲の七ルから発生する炎粒子の個数である.

表 4 より，炎の粒子数が少なければ，本手法での描画 方法のほうが，ボリュームレンダリングよりも高速であ ると言える。本手法は計算時間が解像度に依存すること はなく，粒子数にのみ依存する。また，ポリゴンにより， 炎を描画しているので，画面が多少拡大されてもすき間 が目立ちにくい構造になっている。現時点ではグローバ ルイルミネーションへの対応は行っていないが，文献 ${ }^{6)}$ を用いれば実現可能と考えられる。

\section{8. むすび}

本論文では物体の燃焼表現の一手法について提案した。 仮想空間への応用のため, 見た目の良さと計算量の削減 を重視し，そのためできるだけ複雑な物理モデルを扱わ ず，簡単なパラメータにより燃焼の様子を表現する手法 となっている.

主観的な評価としては燃焼の様子を比較的リアルに表 現でき，また，燃焼物体のパラメー夕を変化させること により, 燃焼の様子をコントロールすることもできた。 燃焼に伴う物体の変形と変色の表現方法の一資料として の価值があるものと考える。

しかし, 現時点のアルゴリズムでは, リアルタイムに 描画することは困難であり，このままでは応用範囲が制 限されることになる。炎の描画に関する処理が全計算時 間のほとんどを占めているため, ドロネー図のアルゴリ ズムの改良や, 別の高速なアルゴリズムの適用などが必 要である．また，木のように収縮変形するものだけでな く，紙のように不規則かつ大きく変形するものや，それ 以外の多様な材質の物体についての変形の実現も今後の 重要な課題である.

\section{〔文献〕}

1) Reeves,W.T.: "Particle systems -A technique of modelling a class of fuzzy objects", SIGGRAPH 83, Computer Graphics, 17, 3, pp.359-376 (1983).

2）高倉 章, 河合直樹, 室田秀樹, 茂出木敏雄: “CG による炎の 3 次元シミュ レーション”，グラフィクスと CAD， 65-2, pp.9-16 (1993)

3）村岡一信, 千葉則茂, 高橋宏通, 三浦 守: “渦場と粒子による煙や炎の 2 次元 CG シミュレーション”, 信学論 (D-II), J76-D-II, 8, pp.1735-1745, Aug. (1993).

4）安居院 猛, 河野雄三, 中嶋正之:“コンピュータグラフィックスにおける火 炎の 2 次元画像の生成”, 信学論 (D-II), J74-D-II，2, pp.184-189, Feb. (1991). 
表 3 各実験における粒子数の平均と計算㭙閒.

Particle average and calculation time.

\begin{tabular}{|c|c|c|c|c|c|}
\hline & Voxel Size & Total Frame & Particle ave.(per frame) & Total Time(min) & Time ave.(min/frame) \\
\hline 汹 $5-(a)$ & $70 \times 60 \times 30$ & 131 & 3455.765 & 87.522 & 0.668 \\
\hline 図 5-(b) & $70 \times 60 \times 30$ & 120 & 4211.892 & 98.159 & 0.818 \\
\hline 闽 6-(a) & $60 \times 50 \times 60$ & 101 & 3818.851 & 76.563 & 0.758 \\
\hline 䒽 6-(b) & $60 \times 50 \times 60$ & 163 & 2491.902 & 80.708 & 0.495 \\
\hline 畄 7 & $50 \times 70 \times 25$ & 182 & 889.890 & 29.799 & 0.164 \\
\hline 図 8 & $100 \times 80 \times 80$ & 509 & 7430.290 & 867.567 & 1.704 \\
\hline
\end{tabular}

表 4 本于法とボリュームレンダリングでの処理㭙間の比較。

The competition of process time on the proposed method and volume rendering.

\begin{tabular}{l|l|r|r|r|r}
\hline \hline \multicolumn{2}{c|}{} & \multicolumn{2}{|c|}{ Proposed method } & \multicolumn{2}{c}{ Volume rendering } \\
\cline { 3 - 6 } \multicolumn{2}{c|}{} & Total frame & Total time $(\min )$ & Total frame & Total time $(\min )$ \\
\hline \multirow{2}{*}{$\begin{array}{l}\text { Resolution } \\
120 \times 120\end{array}$} & 1particle & 132 & 41.683 & 132 & 49.583 \\
\cline { 2 - 6 } & 2particles & 139 & 142.716 & 138 & 51.850 \\
\hline $\begin{array}{l}\text { Resolution } \\
240 \times 240\end{array}$ & 1particle & 132 & 42.000 & 132 & 189.450 \\
\cline { 2 - 6 } & 2particles & 139 & 143.217 & 138 & 196.517 \\
\hline
\end{tabular}

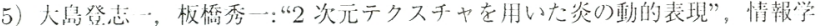
肦卉, 32, 4, pp.435-447 (1991).

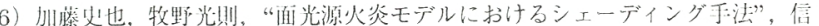
学技㩆, MVE97-107(1998-03), pp.23-30.

7) Jun-ya TAKAHASHI, Hiromichi TAKAHASHI, Norishige CHIBA: "Image Synthesis of Flickering Scenes Including Simulated Flames", IEICE TRANS.INF. \& SYST., E80-D, 11 (NOV. 1997).

8) Holly Rushmeier, Anthony Hamins, Mun Young Choi: "Volume Rendering of Pool Fire Data", IEEE CG\& A (July 1995).

9) J. Stam and E. Fiume: "Depicting Fire and Other Gaseous Phenomena Using Data Diffusion Process", Proc. of SIGGRAPH 95, pp.129-136 (1995).

10）佐藤者将，島田英之，塭野充，宮垣嘉也: “ドロネー三解形分制を用いた炎 の表現方法”, 1998 年映像メディアシンポジウム (IMPS98), pp.87-88 (1998).

11) N. Chiba, S. Ohkawa, K. Muraoka, M. Miura: "Two-dimensional Visual Simulation of Flames, Smoke and the Spread of Fire", The Journal of Visualization and Computer Animation, 5, pp.37-53 (Jan.-Mar. 1994).

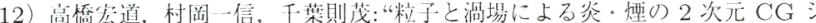
ミュレーション一延焼と連動する燃烧領域を伴う場合一”, 少ラフィクスと CAD, 65-1, pp.1-8 (1993).

13）作滕吉将，島时英之，塩野充，宮堭嘉也：“CGによる物体の燃焼と変形の 表現”，映情技報，24，47，AIT2000-91，pp.7-12 (2000)。

14) David L. Tate, Linda Sibert, Tony King: "Using Virtual Environments to Train Firefighters", IEEE Computer Graphics and Applications, pp.23-29, November/December (1997).

15）泉明英之，作藤吉将，新演直樹，小含不裕二, 程野充: “3 次元 CGによる1 アルタイムな火桨の表現法”，唤情学誌，54，9，pp.1359-1362 (2000)

16）千策期茂，村阔一信其著: “レイトレーシング CG 人阴”，サイエンス祀 (1990).

17) D. Kincard,W. Cheney: "Numerical Analysis", Brooks Cole Pub.Co. (1991).

18）南钽,中村納共著: “画像工学”, コロナ社, pp.94-98 (1989).

19) W.E. Lorensen and H.E. Cline: "Marching cubes: A high resolution 3D surface construction algorithm", Computer Graphics, 21, 4, pp.163-169 (July 1987).

20）F.P.プレパラータ，M.I. シェーモス著，浅野孝犬，浅野哲犬訳: “計算幾 何学入門”, 総研出版, pp.240-242 (1992)

21）中嶋正之監修，テレビジョン学会編: “先端技術の手ほどきシリーズ 3 次元 CG"，オーム社, pp.49-63, (1994)

22）藤代一成・茅植晹著:“ボリュームビジュアライゼーションの基本アルゴリズ 厶", PIXEL, No.121, pp130-137 (1992).

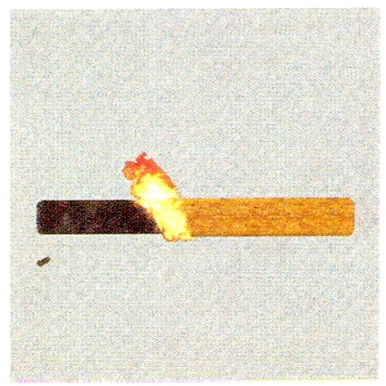

(a) Proposed method

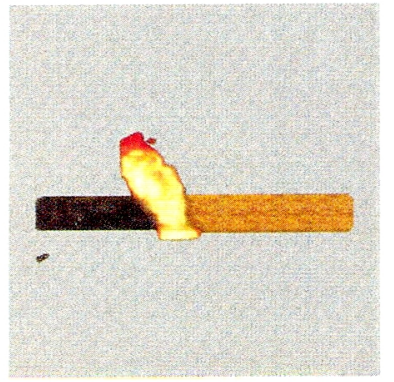

(b) Volume rendering
図 4 本手法とボリュームレンダリングでの結果唡像.

The result images on the proposed method and volume rendering.

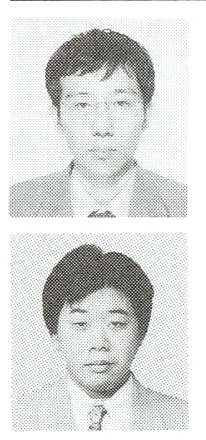

佐藤吉将闹山理科大学大学院修土課程情報工学専 攻了。问大学院システム科学専攻㣪期博士課程を経て, 現 在株式会社ケイ・ジー・ティーに勤務、コンピュータグラ フィックスの犐究・開発に從事。

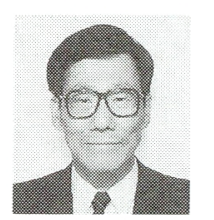

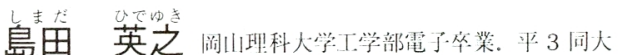
大学院修上課程督子理兴县攻了。同大大学院博上棵程シス

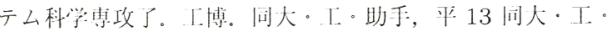

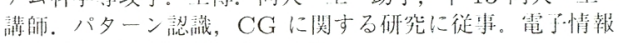
通信学会，情報処歭兴会冬会员。

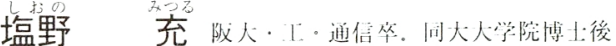

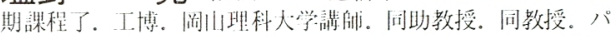

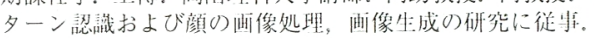

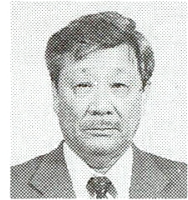

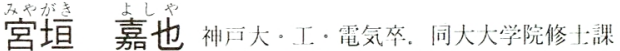

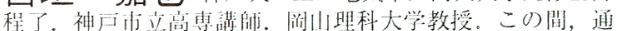
信システム，並列計算㙨，酒像処理の研究に従事。工博。 

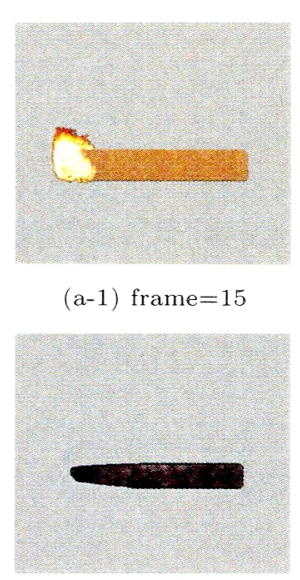

(a-2) frame=131 (a-1) frame $=15$

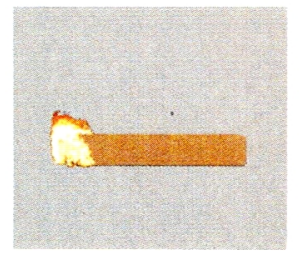

(b-1) frame $=15$

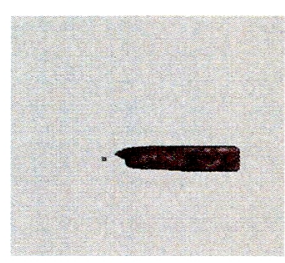

(b-2) frame $=119$ 図 5 收繀窗形り奏行例。

Example of the shrinking deformation.

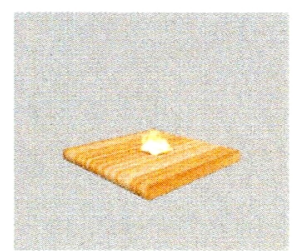

(a-1) frame $=30$

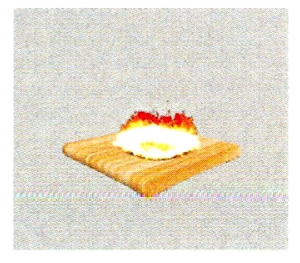

(a-2) frame $=50$

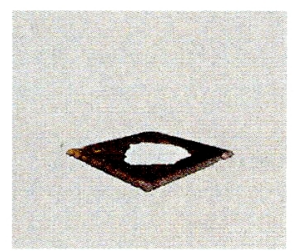

(a-3) frame $=98$

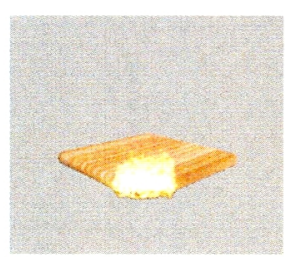

(b-1) frame $=20$

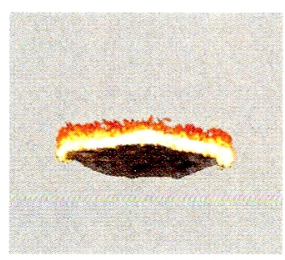

(b-2) frame $=100$

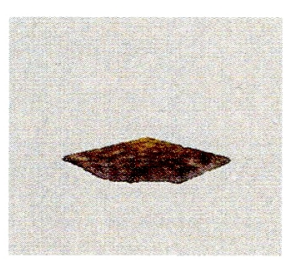

(b-3) frame $=160$
The difference of the origin of the fire.

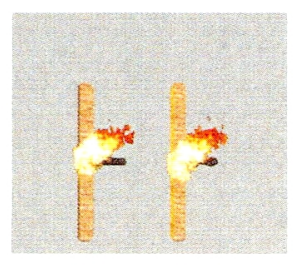

frame $=20$

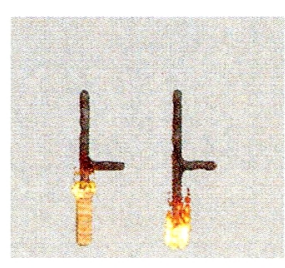

frame $=55$
図 7 上下の熟伀達の違い。

The difference of up-down heat conduction rate.
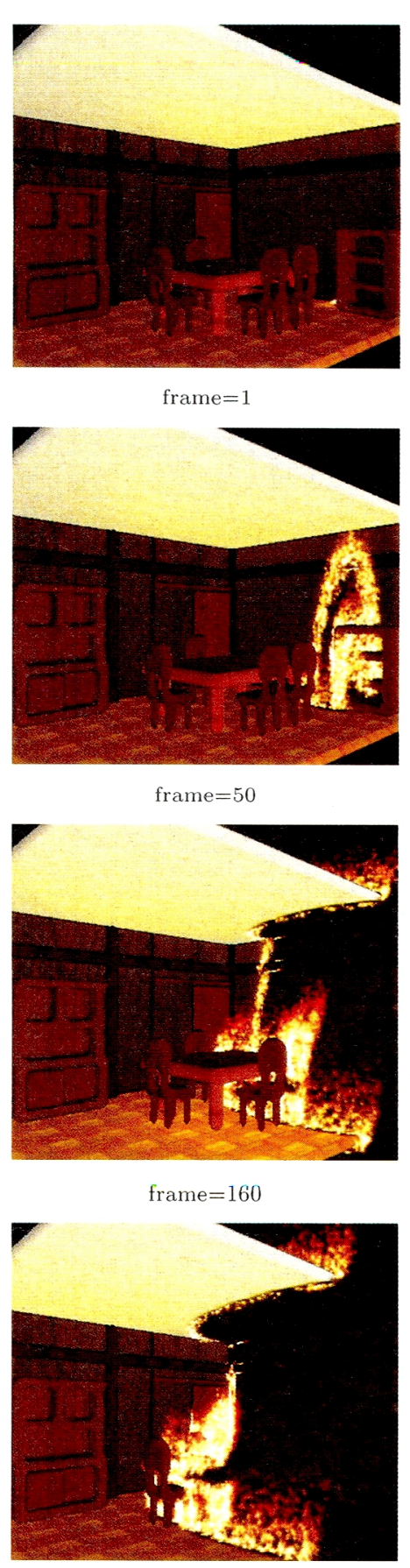

frame $=240$

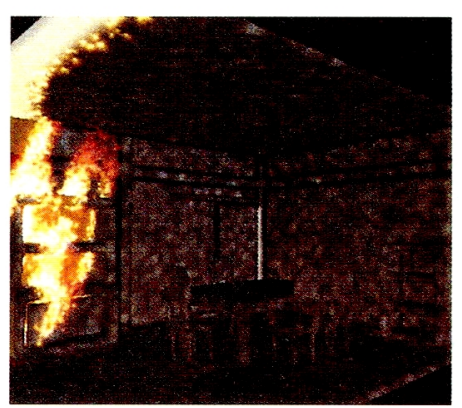

frame $=425$

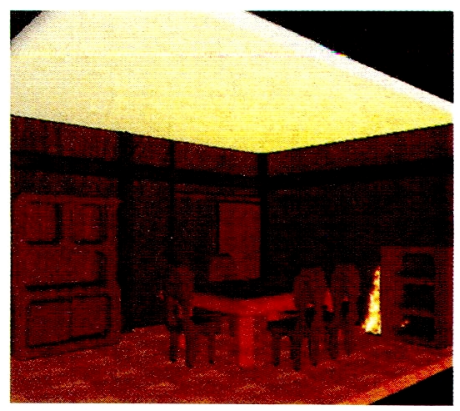

frame $=20$

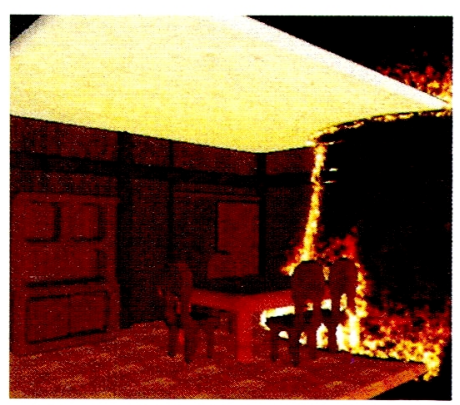

frame $=130$
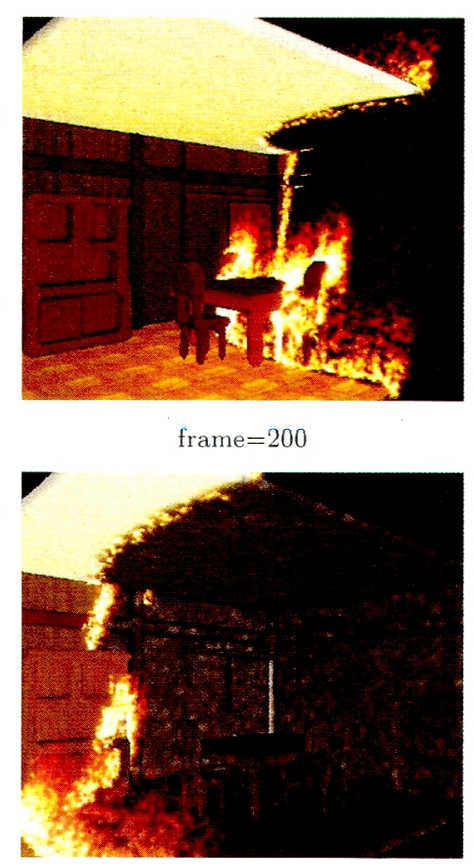

frame $=380$

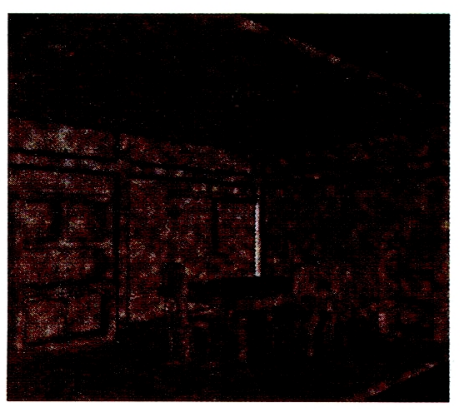

frame $=509$

図 8 燃焼の一例.

An example of the combustion. 